\title{
A Study on Empowerment Quotient of Women in Agriculture Sector - An Empirical Study
}

Hema Srinivasan ${ }^{*}$

\begin{abstract}
India is going to emerge as one of the most developed nations by 2020 with women contributing greatly to it. Women in the agricultural sector play a crucial role in the economic growth of the country. Women in rural areas of the country can influence the other illiterate women to get empowered. This in turn will have a snowball effect in financial and economic terms thereby bringing down gender disparity. For women empowerment, this sector must experience a chain of reforms. This study attempts to investigate the impact of the empowerment quotients on the agricultural women and at the same time study their financial prudence. This study also checks whether the UN sustainable development goals are possible to achieve in India by 2030. The study has some suggestions (such as digital footprints, financial inclusion, demographic dividend reaping, and so on).
\end{abstract}

Keywords: Agricultural Women, Empowerment Quotients, Financial Literacy, Gender Disparity

\section{Introduction}

It has been observed that women comprise about 43 percent of the agricultural labour force in developing countries (mostly in EU and USA). However, this figure is not a true depiction of reality worldwide especially in the developing and underdeveloped

*Jain University, Bengaluru, India; shema14@yahoo.co.in 
countries. From various studies it has been proven that women contribute to the agriculture sectors across the world. They show that a woman's role varies according to crops grown, production cycle, age and ethnic groups. Sometimes, women focus only on general weeding and harvesting activities (Anitha \& Rao, 2013). Overall, the labour burden of rural women exceeds that of men and includes a higher proportion of unpaid household responsibilities related to preparing food and collecting fuel and water. The contribution of women in agricultural and food production is significant but it is impossible to verify the share produced by women empirically. Women participation in rural labour markets varies considerably across regions but invariably women are over represented in unpaid, seasonal and part-time work and the evidence suggests that women are often paid less than men for the same work. It is a known fact that women make essential contributions to agriculture and rural enterprises across the developing world (Arun, 2009). While there is diversity in women's roles, over-generalisation undermines the policy of relevance and planning. The context is important and policies must be based on sound data and gender analysis. Women's equality in power sharing and active participation in decision making including decision making in political process at all levels will be ensured for the achievement of the goals of empowerment.

World Bank Report (2011) states that $17.5 \%$ of India's gross domestic product(GDP) is accounted for by agricultural production. Yet, for a majority of the country, an estimated $72 \%$ of the 1.2 billion people who live in rural India, it is a way of life. Agriculture in India defines familial tradition, social relations and gender roles. It has been often observed that females in the agro sector (both directly and indirectly) represent a mammoth demographic group.

\subsection{Need of the study}

The third MDG or "Millennium Development Goals" of the United Nations is directly related to the empowerment of women and to reducing gender disparity. Their goal is to seek peace and prosperity worldwide which is in no way possible with such a wide gap in gender disparity. Though India is slowly changing 
from an Agro hub to a service industry for the globe, a large portion of its population is into harvesting. Officially, 32.8\% Indian women participate in the labour forces. However, unofficial counts (mostly from rural belts) make that number nearly double. However, when in comparison, male representation stays rock steady (around $81 \%$ ) for more than a decade. The present study has taken into consideration five factors of empowerment namely social, financial, human, intellectual, and leadership skills\& mentoring.

\subsection{Objectives}

1. To study the financial literacy and levels of prudence among women entrepreneurs in agriculture sectors

2. To develop a model for empowerment for women in agriculture sectors

H0- There is no significant relationship between Empowerment Quotient for women entrepreneurs in agriculture sector and the five key factors: social, financial, human, intellectual, and leadership skill \& mentoring factors.

H1 - There is a significant relationship between Empowerment Quotient for women entrepreneurs in agriculture sector and five key factors: social, financial, human, intellectual, and leadership skill \& mentoring factors.

\subsection{Research methodology}

The methodology is based on collection of Primary and Secondary Data.

1. Primary data collection has been through questionnaires, schedules, and personal interviews.

2. Secondary data collection has been through books, journals, records, periodicals, web-sites and the like. 
1.4 Sample size: 380 samples of women working in the education sector

\begin{tabular}{lcc}
\hline & Zone & Education \\
\hline East Zone & 65 \\
West Zone & 67 \\
North Zone & 90 \\
South Zone & 158 \\
Total & 380 \\
\hline
\end{tabular}

\subsection{Sampling method and tools used}

1. Convenience sampling has been adopted to collect the primary data using questionnaires, schedules and focus group interview.

2. Column proportion test and Factor Analysis

\section{Analysis of data and interpretation of Objective 1}

This section elaborates on the analysis and interpretations of objective 1.

Objective 1: To study the financial literacy and levels of prudence among women entrepreneurs in agriculture sectors

Women in agriculture sector| Financial Factors - Earnings| Base: All respondents

\begin{tabular}{|c|c|c|c|c|c|c|c|c|c|c|}
\hline & \multirow{2}{*}{$\begin{array}{c}\text { Total } \\
\text { Total } \\
(\mathrm{A})\end{array}$} & \multicolumn{4}{|c|}{ Zone } & \multicolumn{2}{|c|}{ Place of Living } & \multicolumn{3}{|c|}{ Marital Status } \\
\hline & & $\begin{array}{l}\text { East } \\
\text { (B) }\end{array}$ & $\begin{array}{l}\text { West } \\
\text { (C) }\end{array}$ & $\begin{array}{l}\text { North } \\
\text { (D) }\end{array}$ & $\begin{array}{c}\text { South } \\
\text { (E) }\end{array}$ & $\begin{array}{l}\text { Urban } \\
\text { (F) }\end{array}$ & $\begin{array}{c}\text { Rural } \\
(G)\end{array}$ & $\begin{array}{c}\text { Married } \\
(\mathrm{H})\end{array}$ & $\begin{array}{c}\text { Un } \\
\text { married } \\
(\mathrm{I})\end{array}$ & $\begin{array}{c}\text { Widow/ } \\
\text { Divorce } \\
\text { (J) }\end{array}$ \\
\hline Total & 380 & 65 & 67 & 90 & 158 & $19^{* *}$ & 340 & 319 & $29^{* *}$ & $14^{* *}$ \\
\hline Improved & 34 & 2 & 7 & 5 & 20 & 0 & 32 & 31 & 0 & 2 \\
\hline greatly & $9 \%$ & $3 \%$ & $10 \%$ & $6 \%$ & $13 \% \mathrm{~B}$ & $0 \%$ & $9 \%$ & $10 \%$ & $0 \%$ & $14 \%$ \\
\hline Improved & 251 & 50 & 42 & 67 & 92 & 13 & 225 & 211 & 22 & 3 \\
\hline slightly & $66 \%$ & $77 \% \mathrm{E}$ & $63 \%$ & $74 \% \mathrm{E}$ & $58 \%$ & $68 \%$ & $66 \%$ & $66 \%$ & $76 \%$ & $21 \%$ \\
\hline Stayed & 51 & 8 & 8 & 11 & 24 & 2 & 44 & 41 & 3 & 6 \\
\hline the same & $13 \%$ & $12 \%$ & $12 \%$ & $12 \%$ & $15 \%$ & $11 \%$ & $13 \%$ & $13 \%$ & $10 \%$ & $43 \%$ \\
\hline Shrunk & 2 & 0 & 0 & 1 & 1 & 0 & 2 & 1 & 0 & 1 \\
\hline slightly & $1 \%$ & $0 \%$ & $0 \%$ & $1 \%$ & $1 \%$ & $0 \%$ & $1 \%$ & $0 \%$ & $0 \%$ & $7 \%$ \\
\hline Shrunk & 25 & 3 & 3 & 0 & 17 & 1 & 23 & 22 & 2 & 1 \\
\hline greatly & $7 \%$ & $8 \% \mathrm{D}$ & $4 \% \mathrm{D}$ & $0 \%$ & $11 \% \mathrm{D}$ & $5 \%$ & $7 \%$ & $7 \%$ & $7 \%$ & $7 \%$ \\
\hline Blanks & 17 & 0 & 7 & 6 & 4 & 3 & 14 & 13 & 2 & 1 \\
\hline & $4 \%$ & $0 \%$ & $10 \% \mathrm{BE}$ & $7 \& B$ & $3 \%$ & $16 \%$ & $4 \%$ & $4 \%$ & $7 \%$ & $7 \%$ \\
\hline
\end{tabular}

Proportions/Means: Columns Tested(5\% risk level) B/C/D/E- F/G - H/I/J

Overlap formulae used . ${ }^{*}$ very small base (under 30 )ineligible for sign testing

Fig 1 Column Proportion Test I: Earnings 
Interpretation: $13 \%$ of respondents in South zone agree that their earning has improved greatly. $77 \%$ of respondents in the east zone and $74 \%$ in the North zone agree that their earning has improved slightly. $8 \%$ in the East, $4 \%$ in the West and $11 \%$ in the South zone agree that their earning has shrunk greatly. $10 \%$ of respondents in the West and 7\% in the North zone did not mention anything about their earning. $66 \%$ of respondents in the rural area agree that their earning has improved slightly.

\begin{tabular}{|c|c|c|c|c|c|c|c|c|c|c|}
\hline & \multirow{2}{*}{$\begin{array}{c}\text { Total } \\
\text { Total } \\
\text { (A) }\end{array}$} & \multicolumn{4}{|c|}{ Zone } & \multicolumn{2}{|c|}{ Place of Living } & \multicolumn{3}{|c|}{ Marital Status } \\
\hline & & $\begin{array}{l}\text { East } \\
\text { (B) }\end{array}$ & $\begin{array}{c}\text { West } \\
\text { (C) }\end{array}$ & $\begin{array}{l}\text { North } \\
\text { (D) }\end{array}$ & $\begin{array}{l}\text { South } \\
\text { (E) }\end{array}$ & $\begin{array}{c}\text { Urban } \\
(\mathrm{F})\end{array}$ & $\begin{array}{c}\text { Rural } \\
(G)\end{array}$ & $\begin{array}{c}\text { Married } \\
(\mathrm{H})\end{array}$ & $\begin{array}{c}\text { Un } \\
\text { married } \\
(\mathrm{I})\end{array}$ & Others \\
\hline Total & 380 & 65 & 67 & 90 & 158 & 19 & 340 & 319 & 29 & 34 \\
\hline Improved & 44 & 02 & 11 & 05 & 26 & 0 & 43 & 38 & 01 & 02 \\
\hline greatly & $12 \%$ & $03 \%$ & $16 \%$ & $06 \%$ & $16 \%$ & 0 & $13 \%$ & $12 \%$ & $03 \%$ & $14 \%$ \\
\hline Improved & 239 & 50 & 42 & 65 & 82 & 13 & 215 & 205 & 18 & 05 \\
\hline slightly & $63 \%$ & $77 \%$ & $63 \%$ & $72 \%$ & $52 \%$ & $68 \%$ & $63 \%$ & $64 \%$ & $62 \%$ & $36 \%$ \\
\hline Stayed & 58 & 08 & 07 & 12 & 31 & 03 & 47 & 44 & 06 & 05 \\
\hline the same & $15 \%$ & $12 \%$ & $10 \%$ & $13 \%$ & $20 \%$ & $16 \%$ & $14 \%$ & $14 \%$ & $21 \%$ & $36 \%$ \\
\hline Shrunk & 01 & 0 & 0 & 0 & 01 & 0 & 01 & 01 & 0 & 0 \\
\hline slightly & $0 \%$ & & & & $0 \%$ & & $0 \%$ & $0 \%$ & & \\
\hline Shrunk & 25 & 05 & 03 & 0 & 17 & 01 & 23 & 22 & 02 & 01 \\
\hline greatly & $6 \%$ & $08 \%$ & $0 \%$ & $02 \%$ & $09 \%$ & $0 \%$ & $06 \%$ & $05 \%$ & $07 \%$ & $14 \%$ \\
\hline Blanks & 17 & 0 & 07 & 06 & 04 & 14 & 13 & 02 & 01 & 01 \\
\hline & $4 \%$ & & $10 \%$ & $07 \%$ & $03 \%$ & $16 \%$ & $04 \%$ & $04 \%$ & $07 \%$ & $0 \%$ \\
\hline
\end{tabular}

Fig 2 Column Proportion Test II Household expenditure

Interpretation: $16 \%$ of respondents in the West and South zone agree that their household expenditure has improved greatly. $77 \%$ of respondents in the East and $72 \%$ in the North zone agree that their household expenditure has improved slightly. $8 \%$ in the East and $9 \%$ in the South zone agree that their household expenditure has shrunk greatly. $10 \%$ of respondents in the West and $7 \%$ in the North zone did not mention anything about household expenditure. $63 \%$ of respondents in rural area agree that their household expenditure has improved slightly. $64 \%$ of married respondents agree that their household expenditure has improved slightly. 


\begin{tabular}{|c|c|c|c|c|c|c|c|c|c|c|}
\hline & \multirow{2}{*}{$\begin{array}{c}\text { Total } \\
\text { Total } \\
\text { (A) }\end{array}$} & \multicolumn{4}{|c|}{ Zone } & \multicolumn{2}{|c|}{ Place of Living } & \multicolumn{3}{|c|}{ Marital Status } \\
\hline & & $\begin{array}{l}\text { East } \\
\text { (B) }\end{array}$ & $\begin{array}{l}\text { West } \\
\text { (C) }\end{array}$ & $\begin{array}{l}\text { North } \\
\text { (D) }\end{array}$ & $\begin{array}{l}\text { South } \\
\text { (E) }\end{array}$ & $\begin{array}{c}\text { Urban } \\
\text { (F) }\end{array}$ & $\begin{array}{c}\text { Rural } \\
(\mathrm{G})\end{array}$ & $\begin{array}{c}\text { Married } \\
(\mathrm{H})\end{array}$ & $\begin{array}{c}\text { Un } \\
\text { married } \\
(\mathrm{I})\end{array}$ & Others \\
\hline Total & 380 & 65 & 67 & 90 & 158 & 19 & 340 & 319 & 29 & 34 \\
\hline Improved & 67 & 06 & 17 & 10 & 34 & 0 & 65 & 59 & 02 & 01 \\
\hline greatly & $18 \%$ & $09 \%$ & $25 \%$ & $11 \%$ & $22 \%$ & & $19 \%$ & $18 \%$ & $7 \%$ & $7 \%$ \\
\hline Improved & 196 & 44 & 31 & 54 & 67 & 13 & 172 & 159 & 19 & 07 \\
\hline slightly & $52 \%$ & $68 \%$ & $46 \%$ & $60 \%$ & $42 \%$ & $68 \%$ & $51 \%$ & $50 \%$ & $66 \%$ & $50 \%$ \\
\hline Stayed & 68 & 12 & 10 & 11 & 35 & 02 & 60 & 59 & 06 & 01 \\
\hline the same & $18 \%$ & $18 \%$ & $15 \%$ & $12 \%$ & $22 \%$ & $11 \%$ & $18 \%$ & $18 \%$ & $21 \%$ & $07 \%$ \\
\hline Shrunk & 02 & 01 & 0 & 0 & 1 & 0 & 1 & 02 & 02 & 0 \\
\hline slightly & $01 \%$ & $2 \%$ & & & $1 \%$ & & $0 \%$ & $0 \%$ & $0 \%$ & \\
\hline Shrunk & 26 & 1 & 1 & 8 & 16 & 0 & 24 & 23 & 0 & 03 \\
\hline greatly & $7 \%$ & $2 \%$ & $1 \%$ & $9 \%$ & $10 \%$ & & $07 \%$ & $07 \%$ & & $21 \%$ \\
\hline Blanks & 21 & 1 & 8 & 7 & 5 & 4 & 17 & 17 & 02 & 02 \\
\hline & $6 \%$ & $2 \%$ & $12 \%$ & $8 \%$ & $3 \%$ & $21 \%$ & $5 \%$ & $5 \%$ & $7 \%$ & $14 \%$ \\
\hline
\end{tabular}

Fig 3 Column Proportion Test III expenditure on household durables

Interpretation: $25 \%$ of respondents in the West and $22 \%$ in the South zone agree that their expenditure on household durables has improved greatly. $68 \%$ of respondents in the East and $60 \%$ in the North zone agree that their expenditure on household durables has improved slightly. $10 \%$ in the South zone agree that their expenditure on household durables has shrunk greatly. $51 \%$ of respondents in rural area agree that their expenditure on household durables has improved slightly. 50\% of married respondents agree that their expenditure on household durables has improved slightly.

\begin{tabular}{lcccccccccc}
\hline & Total & \multicolumn{3}{c}{ Zone } & \multicolumn{3}{c}{ Place of Living } & \multicolumn{3}{c}{ Marital Status } \\
& $\begin{array}{c}\text { Total } \\
\text { (A) }\end{array}$ & $\begin{array}{c}\text { East } \\
\text { (B) }\end{array}$ & $\begin{array}{c}\text { West } \\
(\mathrm{C})\end{array}$ & $\begin{array}{c}\text { North } \\
(\mathrm{D})\end{array}$ & $\begin{array}{c}\text { South } \\
(\mathrm{E})\end{array}$ & $\begin{array}{c}\text { Urban } \\
(\mathrm{F})\end{array}$ & $\begin{array}{c}\text { Rural } \\
(\mathrm{G})\end{array}$ & $\begin{array}{c}\text { Married } \\
(\mathrm{H})\end{array}$ & $\begin{array}{c}\text { Un } \\
\text { married } \\
(\mathrm{I})\end{array}$ & Others \\
\hline Total & 380 & 65 & 67 & 90 & 158 & 19 & 340 & 319 & 29 & 34 \\
Improved & 82 & 10 & 21 & 16 & 35 & 1 & 78 & 73 & 4 & 1 \\
greatly & $22 \%$ & $15 \%$ & $31 \%$ & $18 \%$ & $22 \%$ & $5 \%$ & $23 \%$ & $23 \%$ & $14 \%$ & $7 \%$ \\
Improved & 144 & 39 & 25 & 31 & 49 & 7 & 126 & 112 & 16 & 6 \\
slightly & $38 \%$ & $60 \%$ & $37 \%$ & $34 \%$ & $31 \%$ & $37 \%$ & $37 \%$ & $35 \%$ & $55 \%$ & $43 \%$ \\
Stayed & 88 & 13 & 8 & 24 & 43 & 4 & 80 & 76 & 5 & 4 \\
the same & $23 \%$ & $20 \%$ & $12 \%$ & $27 \%$ & $27 \%$ & $21 \%$ & $24 \%$ & $24 \%$ & $17 \%$ & $29 \%$ \\
Shrunk & 2 & 1 & 0 & 0 & 1 & 0 & 2 & 2 & 0 & 0 \\
slightly & $1 \%$ & $2 \%$ & 0 & 0 & $1 \%$ & 0 & $1 \%$ & $1 \%$ & 0 & 0 \\
Shrunk & 35 & 0 & 1 & 12 & 22 & 1 & 32 & 31 & 1 & 2 \\
greatly & $9 \%$ & 0 & $1 \%$ & $13 \%$ & $14 \%$ & $5 \%$ & $9 \%$ & $10 \%$ & $3 \%$ & $14 \%$ \\
Blanks & 29 & 2 & 12 & 7 & 8 & 6 & 22 & 25 & 3 & 1 \\
& $8 \%$ & $3 \%$ & $18 \%$ & $8 \%$ & $5 \%$ & $32 \%$ & $6 \%$ & $8 \%$ & $10 \%$ & $7 \%$ \\
\hline
\end{tabular}


Interpretation: $31 \%$ of the respondents in the West zone agree that their ability to save on healthcare expenses has improved greatly. $60 \%$ of respondents in the East zone agree that their ability to save on healthcare expenses has improved slightly. $27 \%$ in the South zone agree that their ability to save on healthcare expenses has stayed the same. $18 \%$ of the respondents in the West zone did not mention anything about the ability to save on healthcare expenses. $13 \%$ in the North and $14 \%$ in the South zone agree that their ability to save on healthcare expenses has shrunk greatly. $37 \%$ of the respondents in Rural area agree that their ability to save on healthcare expenses has improved slightly. 35\% of the married respondents agree that their ability to save on healthcare expenses has improved slightly.

\begin{tabular}{|c|c|c|c|c|c|c|c|c|c|c|}
\hline & \multirow{2}{*}{$\begin{array}{l}\text { Total } \\
\text { Total } \\
\text { (A) }\end{array}$} & \multicolumn{4}{|c|}{ Zone } & \multicolumn{2}{|c|}{ Place of Living } & \multicolumn{3}{|c|}{ Marital Status } \\
\hline & & $\begin{array}{l}\text { East } \\
\text { (B) }\end{array}$ & $\begin{array}{l}\text { West } \\
\text { (C) }\end{array}$ & $\begin{array}{l}\text { North } \\
\text { (D) }\end{array}$ & $\begin{array}{l}\text { South } \\
\text { (E) }\end{array}$ & $\begin{array}{l}\text { Urban } \\
\text { (F) }\end{array}$ & $\begin{array}{c}\text { Rural } \\
(\mathrm{G})\end{array}$ & $\begin{array}{c}\text { Married } \\
(\mathrm{H})\end{array}$ & $\begin{array}{c}\text { Un } \\
\text { married } \\
(\mathrm{I})\end{array}$ & Others \\
\hline Total & 380 & 65 & 67 & 19 & 158 & 19 & 340 & 319 & 29 & 34 \\
\hline Improved & 95 & 21 & 18 & 21 & 35 & 04 & 85 & 80 & 09 & 01 \\
\hline greatly & $25 \%$ & $32 \%$ & $27 \%$ & $23 \%$ & $22 \%$ & $21 \%$ & $25 \%$ & $25 \%$ & $31 \%$ & $07 \%$ \\
\hline Improved & 123 & 20 & 41 & 15 & 47 & 09 & 106 & 101 & 09 & 06 \\
\hline slightly & $32 \%$ & $31 \%$ & $61 \%$ & $17 \%$ & $30 \%$ & $47 \%$ & $31 \%$ & $32 \%$ & $31 \%$ & $43 \%$ \\
\hline Stayed & 103 & 22 & 04 & 37 & 40 & 04 & 94 & 85 & 08 & 04 \\
\hline the same & $27 \%$ & $34 \%$ & $06 \%$ & $25 \%$ & $21 \%$ & $28 \%$ & $27 \%$ & $28 \%$ & $29 \%$ & $29 \%$ \\
\hline Shrunk & 02 & 01 & 0 & 0 & 01 & 0 & 02 & 02 & 0 & 0 \\
\hline slightly & $01 \%$ & $02 \%$ & & & $01 \%$ & & $01 \%$ & $01 \%$ & & \\
\hline Shrunk & 42 & 02 & 01 & 11 & 28 & 0 & 41 & 39 & 01 & 02 \\
\hline greatly & $11 \%$ & $03 \%$ & $01 \%$ & $12 \%$ & $18 \%$ & & $12 \%$ & $12 \%$ & $03 \%$ & $14 \%$ \\
\hline Blanks & 17 & 0 & 03 & 06 & 08 & 02 & 14 & 14 & 02 & 01 \\
\hline & $4 \%$ & & $04 \%$ & $07 \%$ & $05 \%$ & $11 \%$ & $04 \%$ & $04 \%$ & $07 \%$ & $07 \%$ \\
\hline
\end{tabular}

Fig 5 Column Proportion Test V Ability to save on educational expenses

Interpretation: $61 \%$ of the respondents in the West and $30 \%$ in South zone agree that their ability to save on educational expenses has improved slightly. $34 \%$ of respondents in the East, $41 \%$ in the North and 25\% in the South zone agree that their ability to save on educational expenses has stayed the same. $12 \%$ in the North and $18 \%$ in the South zone agree that their ability to save on educational expenses has shrunk greatly. $7 \%$ of the respondents in the North zone did not mention anything about the ability to save on educational expenses. $31 \%$ of respondents in the Rural area agree that their ability to save on educational expenses has improved 
slightly. $32 \%$ of the married respondents agree that their ability to save on educational expenses has improved slightly.

\begin{tabular}{lcccccccccc}
\hline & Total & \multicolumn{3}{c}{ Zone } & \multicolumn{3}{c}{ Place of Living } & \multicolumn{3}{c}{ Marital Status } \\
& $\begin{array}{c}\text { Total } \\
\text { (A) }\end{array}$ & $\begin{array}{c}\text { East } \\
(\mathrm{B})\end{array}$ & $\begin{array}{c}\text { West } \\
(\mathrm{C})\end{array}$ & $\begin{array}{c}\text { North } \\
(\mathrm{D})\end{array}$ & $\begin{array}{c}\text { South } \\
(\mathrm{E})\end{array}$ & $\begin{array}{c}\text { Urban } \\
(\mathrm{F})\end{array}$ & $\begin{array}{c}\text { Rural } \\
(\mathrm{G})\end{array}$ & $\begin{array}{c}\text { Married } \\
(\mathrm{H})\end{array}$ & $\begin{array}{c}\text { Un } \\
\text { married } \\
(\mathrm{I})\end{array}$ & Others \\
\hline Total & 380 & 65 & 67 & 90 & 158 & 19 & 340 & 319 & 29 & 34 \\
Improved & 91 & 18 & 15 & 21 & 37 & 3 & 82 & 78 & 8 & 0 \\
greatly & $24 \%$ & $28 \%$ & $22 \%$ & $23 \%$ & $23 \%$ & $16 \%$ & $24 \%$ & $24 \%$ & $28 \%$ & 0 \\
Improved & 124 & 22 & 36 & 17 & 49 & 5 & 113 & 105 & 7 & 5 \\
slightly & $33 \%$ & $34 \%$ & $54 \%$ & $19 \%$ & $31 \%$ & $26 \%$ & $33 \%$ & $33 \%$ & $24 \%$ & $36 \%$ \\
Stayed & 94 & 22 & 6 & 29 & 37 & 5 & 85 & 72 & 12 & 6 \\
the same & $25 \%$ & $34 \%$ & $9 \%$ & $32 \%$ & $23 \%$ & $26 \%$ & $25 \%$ & $23 \%$ & $41 \%$ & $43 \%$ \\
Shrunk & 52 & 3 & 2 & 16 & 31 & 1 & 47 & 49 & 0 & 2 \\
greatly & $14 \%$ & $5 \%$ & $3 \%$ & $18 \%$ & $20 \%$ & $5 \%$ & $14 \%$ & $15 \%$ & & $14 \%$ \\
Blanks & 19 & 0 & 8 & 7 & 4 & 5 & 13 & 15 & 2 & 1 \\
& $5 \%$ & & $12 \%$ & $8 \%$ & $3 \%$ & $26 \%$ & $4 \%$ & $5 \%$ & $7 \%$ & $7 \%$ \\
\hline
\end{tabular}

Fig 6 Column Proportion Test VI ability to invest on fixed assets

Interpretation: $34 \%$ of the respondents in the East, $54 \%$ in the North and $31 \%$ in the South zone agree that their ability to invest on fixed assets has improved slightly. $34 \%$ of the respondents in East, $32 \%$ in the North and $23 \%$ in the South zone agree that their ability to invest on fixed assets has stayed the same. $18 \%$ in the North and $20 \%$ in the South zone agree that their ability to invest on fixed assets has shrunk greatly. $12 \%$ of the respondents in the West and $8 \%$ in the North zone did not mention anything about the ability to invest on fixed assets. 33\% of respondents in the Rural area agree that their ability to invest on fixed assets has improved slightly. $33 \%$ of the married respondents agree that their ability to invest on fixed assets has improved slightly. 
Hema Srinivasan Empowerment Quotient of Women in Agriculture Sector

\begin{tabular}{lcccccccccc}
\hline & Total & \multicolumn{3}{c}{ Zone } & \multicolumn{3}{c}{ Place of Living } & \multicolumn{3}{c}{ Marital Status } \\
\hline & $\begin{array}{c}\text { Total } \\
\text { (A) }\end{array}$ & $\begin{array}{c}\text { East } \\
(\mathrm{B})\end{array}$ & $\begin{array}{c}\text { West } \\
(\mathrm{C})\end{array}$ & $\begin{array}{c}\text { North } \\
(\mathrm{D})\end{array}$ & $\begin{array}{c}\text { South } \\
(\mathrm{E})\end{array}$ & $\begin{array}{c}\text { Urban } \\
(\mathrm{F})\end{array}$ & $\begin{array}{c}\text { Rural } \\
(\mathrm{G})\end{array}$ & $\begin{array}{c}\text { Married } \\
(\mathrm{H})\end{array}$ & $\begin{array}{c}\text { Un } \\
\text { married } \\
(\mathrm{I})\end{array}$ & Others \\
\hline Total & 380 & 65 & 67 & 90 & 158 & $19^{* *}$ & 340 & 319 & $29^{* *}$ & $34^{* *}$ \\
Improved & 85 & 16 & 17 & 19 & 33 & 2 & 77 & 74 & 6 & 0 \\
greatly & $22 \%$ & $25 \%$ & $25 \%$ & $21 \%$ & $21 \%$ & $11 \%$ & $23 \%$ & $23 \%$ & $21 \%$ & \\
Improved & 114 & 21 & 26 & 19 & 48 & 5 & 105 & 97 & 8 & 4 \\
slightly & $30 \%$ & $32 \%$ & $39 \%$ & $21 \%$ & $30 \%$ & $26 \%$ & $31 \%$ & $30 \%$ & $28 \%$ & $29 \%$ \\
Stayed & 101 & 25 & 11 & 27 & 38 & 6 & 88 & 77 & 12 & 6 \\
the same & $27 \%$ & $38 \%$ & $16 \%$ & $30 \%$ & $24 \%$ & $32 \%$ & $26 \%$ & $24 \%$ & $41 \%$ & $43 \%$ \\
Shrunk & 59 & 3 & 2 & 19 & 35 & 0 & 55 & 55 & 1 & 2 \\
greatly & $16 \%$ & $5 \%$ & $3 \%$ & $21 \%$ & $22 \%$ & & $16 \%$ & $17 \%$ & $3 \%$ & $14 \%$ \\
Blanks & 21 & 0 & 11 & 6 & 4 & 6 & 15 & 16 & 2 & 2 \\
& $6 \%$ & & $16 \%$ & $7 \%$ & $3 \%$ & $32 \%$ & $4 \%$ & $5 \%$ & $7 \%$ & $14 \%$ \\
\hline
\end{tabular}

Fig 7 Column Proportion Test VII Ability to invest on non-fixed assets

Interpretation: $39 \%$ of the respondents in the West zone agree that investments on non-fixed assets have improved slightly. 38\% of the respondents in the East zone agree that investments on non-fixed assets have stayed the same. $21 \%$ in the North and $22 \%$ in the South zone agree that investments on non-fixed assets have shrunk greatly. $16 \%$ of the respondents in the West and 7\% in the North zone did not mention anything about investments on non-fixed assets. $31 \%$ of the respondents in the Rural area agree that investments on non-fixed assets has improved slightly. $30 \%$ of the married respondents agree that investments on non-fixed assets have improved slightly.

\begin{tabular}{|c|c|c|c|c|c|c|c|c|c|c|}
\hline & \multirow{2}{*}{$\begin{array}{c}\text { Total } \\
\text { Total } \\
\text { (A) }\end{array}$} & \multicolumn{4}{|c|}{ Zone } & \multicolumn{2}{|c|}{ Place of Living } & \multicolumn{3}{|c|}{ Marital Status } \\
\hline & & $\begin{array}{l}\text { East } \\
\text { (B) }\end{array}$ & $\begin{array}{l}\text { West } \\
\text { (C) }\end{array}$ & $\begin{array}{l}\text { North } \\
\text { (D) }\end{array}$ & $\begin{array}{l}\text { South } \\
\text { (E) }\end{array}$ & $\begin{array}{l}\text { Urban } \\
\text { (F) }\end{array}$ & $\begin{array}{c}\text { Rural } \\
(G)\end{array}$ & $\begin{array}{c}\text { Married } \\
(\mathrm{H})\end{array}$ & $\begin{array}{c}\text { Un } \\
\text { married } \\
(\mathrm{I})\end{array}$ & Others \\
\hline Occupation & 380 & 65 & 67 & 90 & 158 & $19^{* *}$ & 340 & 319 & $29^{* *}$ & $34^{* *}$ \\
\hline \multirow[t]{2}{*}{ Agriculture } & 158 & 31 & 14 & 35 & 78 & 2 & 145 & 139 & 8 & 4 \\
\hline & $42 \%$ & $48 \%$ & $21 \%$ & $39 \%$ & $49 \%$ & $11 \%$ & $43 \%$ & $44 \%$ & $28 \%$ & $29 \%$ \\
\hline Animal & 22 & 5 & 1 & 8 & 8 & 1 & 20 & 17 & 2 & 1 \\
\hline Husbandry & $6 \%$ & $8 \%$ & $1 \%$ & $9 \%$ & $5 \%$ & $5 \%$ & $6 \%$ & $5 \%$ & $7 \%$ & $7 \%$ \\
\hline Income & 91 & 11 & 32 & 18 & 30 & 13 & 72 & 77 & 3 & 5 \\
\hline $\begin{array}{l}\text { generating } \\
\text { activities }\end{array}$ & $24 \%$ & $17 \%$ & $48 \%$ & $20 \%$ & $19 \%$ & $68 \%$ & $21 \%$ & $24 \%$ & $10 \%$ & $36 \%$ \\
\hline \multirow[t]{2}{*}{ Buildings } & 15 & 10 & 0 & 2 & 3 & 0 & 15 & 10 & 5 & 0 \\
\hline & $4 \%$ & $15 \%$ & & $2 \%$ & $2 \%$ & & $4 \%$ & $13 \%$ & $17 \%$ & \\
\hline Medical & 2 & 0 & 0 & 1 & 1 & 2 & 2 & 0 & 1 & 2 \\
\hline Education & $1 \%$ & & & $1 \%$ & $1 \%$ & $1 \%$ & $1 \%$ & & $3 \%$ & $14 \%$ \\
\hline \multirow[t]{2}{*}{ Others } & 4 & 0 & 3 & 0 & 1 & 2 & 4 & 0 & 0 & 1 \\
\hline & $1 \%$ & & $4 \%$ & & $1 \%$ & $5 \%$ & $1 \%$ & & & $7 \%$ \\
\hline \multirow[t]{2}{*}{ Blanks } & 88 & 8 & 17 & 26 & 37 & 2 & 84 & 70 & 11 & 4 \\
\hline & $23 \%$ & $12 \%$ & $25 \%$ & $29 \%$ & $23 \%$ & $11 \%$ & $25 \%$ & $25 \%$ & $22 \%$ & $28 \%$ \\
\hline
\end{tabular}


Interpretation: $39 \%$ of the respondents in the North and $49 \%$ in the South zone took loan for agriculture. $48 \%$ of the respondents in the West zone took loan for income generating activities. $15 \%$ of the respondents in the East zone took loans for buildings. $4 \%$ of the respondents in the East zone took loans for other reason. 29\% of the respondents in the North did not mention anything about the purpose of the loan. $43 \%$ of the respondents in the Rural area took loan for agriculture. $44 \%$ of the married respondents took loan for agriculture.

\section{Empowerment model of women in agriculture sector}

This section elaborates on the analysis and interpretations of Objective 2.

\subsection{Objectives and hypotheses}

Objective 2: To develop a model for empowerment of women in the agriculture sector.

H0 - There is no significant relationship between Empowerment Quotient for women entrepreneurs in the agriculture sector and five key factors: social, financial, human, intellectual, and leadership skill \&mentoring factors.

H1 - There is a significant relationship between Empowerment Quotient for women entrepreneurs in agriculture sector and five key factors: social, financial, human, intellectual, and leadership skill \& mentoring factors.

\subsection{Factors used for the study}

The various factors that the study has taken into consideration are as follows:

1. Social Factors: Defined as the relationship between a woman and her family members.

2. Human Factors: Defined as leadership skills and home-life balance.

3. Financial Factors: Defined as a woman's personal assets, earnings, savings, and knowledge of financial matters. 
4. Intellectual Factors: Defined as a woman's knowledge of legal rights, work experience, and decision making capacities.

5. Leadership Skills and Mentoring Factors: Refer to skills a woman possesses and the kind of mentoring she requires for her development.

The questions that have been used in the analyses are provided as Section B, C, D, E, F and Empowerment Quotient for women entrepreneurs (questionnaire attached as an appendix).

Correlation - There is a positive correlation (Pearson) between the overall Empowerment Quotient for women entrepreneurs and the five key factors. P-value is 0.001 which rejects the null hypothesis. Hence there is a relationship between the overall Empowerment Quotient for women entrepreneurs and the five factors.

\subsection{Analysis}

Using Regression Analysis, we found that there is a significant relationship between Empowerment Quotient for women entrepreneurs and five key factors. Hence multiple regression analysis rejects the null hypothesis.

Table 1 Result of Analysis of Variance between Empowerment Quotient for women entrepreneurs and five key factors

\begin{tabular}{lc}
\hline \multicolumn{2}{c}{ Goodness of fit statistics: } \\
\hline Observations & 354 \\
Sum of weights & 354 \\
DF & 348 \\
$\mathrm{R}^{2}$ & 0.978 \\
Adjusted R & 0.978 \\
DW & 1.9 \\
\hline
\end{tabular}

\begin{tabular}{lccccc}
\hline \multicolumn{6}{c}{ Analysis of variance: } \\
\hline & Sum of Squares & df & Mean Square & F & Sig. \\
Regression & 3.465755 & 5 & 0.693151 & 3086.916 & $9.5 \mathrm{E}-286$ \\
Residual & 0.078142 & 348 & 0.000225 & & \\
Total & 3.543896 & 353 & & & \\
\hline
\end{tabular}


Table 2 Result - Financial and human factors are most important for the overall Empowerment Quotient for women entrepreneurs in agriculture sector

\begin{tabular}{lccccc}
\hline & $\begin{array}{c}\text { Un standardised } \\
\text { Coefficients }\end{array}$ & \multicolumn{3}{c}{$\begin{array}{c}\text { Standardised } \\
\text { Coefficients }\end{array}$} \\
\hline & beta & Std. Error & Beta & $\mathrm{t}$ & Sig. \\
(Constant) & 0.809689 & 0.005363 & & 150.9875 & 0 \\
Social Factors & 0.176078 & 0.008637 & 0.186325 & 20.38739 & $2.36 \mathrm{E}-61$ \\
Financial Factors & 0.213754 & 0.006421 & 0.296576 & 33.28961 & $3.3 \mathrm{E}-110$ \\
Human Factors & 0.207442 & 0.007544 & 0.236507 & 27.49854 & $2.88 \mathrm{E}-89$ \\
Intellectual Factors & 0.20212 & 0.007418 & 0.340136 & 27.24846 & $2.53 \mathrm{E}-88$ \\
Leadership Skills & 0.201709 & 0.007645 & 0.331485 & 26.38589 & $4.83 \mathrm{E}-85$ \\
and mentoring & & & & & \\
\hline
\end{tabular}

Equation of Model: Empowerment Quotient for women entrepreneurs $=0.81+0.18^{*}$ Social Factors $+0.21 *$ Financial Factors $+0.21 *$ Human Factors $+0.20 *$ Intellectual Factors $+0.20 *$ Skill Development \& training

Interpretation: The Null Hypothesis which says that there is no relationship between overall Empowerment Quotient for women entrepreneurs and five factors has got rejected.

The alternate hypothesis is accepted as there is a positive correlation between the Empowerment Quotient for women entrepreneurs in Agriculture sector and all the above five mentioned factors. Among the five factors of empowerment quotient, the factors which have the maximum impact are financial factors and Human factors.

\subsubsection{Findings of Objective 1}

Earnings: It has been found that $13 \%$ of respondents in the South zone agree that their earning has improved greatly. $77 \%$ of the respondents in the east zone and $74 \%$ in the North zone agree that their earning has improved slightly. $8 \%$ in the East, $4 \%$ in the West and $11 \%$ in the South zone agree that their earning has shrunk greatly. $10 \%$ of the respondents in the West and $7 \%$ in the North zone did not mention anything about their earning. $66 \%$ of the respondents in the Rural area agree that their earning has improved slightly. 
Household expenses: It has been found that $16 \%$ of the respondents in the West and the South zone agree that their household expenditure has improved greatly. $77 \%$ of the respondents in the East and $72 \%$ in the North zone agree that their household expenditure has improved slightly. $8 \%$ in the East and $9 \%$ in the South zone agree that their household expenditure has shrunk greatly. $10 \%$ of the respondents in the West and $7 \%$ in the North zone did not mention anything about household expenditure. $63 \%$ of the respondents in the Rural area agree that their household expenditure has improved slightly. $64 \%$ of the married respondents agree that their household expenditure has improved slightly.

Expenses on household durables: From the study, it is inferred that $25 \%$ of the respondents in the West zone and $22 \%$ in the South zone agree that their expenditure on household durables has improved greatly. $68 \%$ of the respondents in the East and $60 \%$ in the North zone agree that their expenditure on household durables has improved slightly. $10 \%$ in the South zone agree that their expenditure on household durables has shrunk greatly. $12 \%$ of the respondents in the West zone did not mention anything about expenditure on household durables. $51 \%$ of the respondents in Rural area agree that their expenditure on household durables has improved slightly. 50\% of the married respondents agree that their expenditure on household durables has improved slightly.

Ability to save for healthcare: $31 \%$ of the respondents in the West zone agree that their ability to save on healthcare expenses has improved greatly. $60 \%$ of the respondents in the East zone agree that their ability to save on healthcare expenses has improved slightly. $27 \%$ in the South zone agree that their ability to save on healthcare expenses has stayed the same. $18 \%$ of the respondents in the West zone did not mention anything about ability to save on healthcare expenses. $13 \%$ in the North and $14 \%$ in the South zone agree that their ability to save on healthcare expenses has shrunk greatly. $37 \%$ of the respondents in the Rural area agree that their ability to save on healthcare expenses has improved slightly. 35\% of the married respondents agree that their ability to save on healthcare expenses has improved slightly. 
Ability to save for education of children: $61 \%$ of the respondents in the West and 30\% in the South zone agree that their ability to save on educational expenses has improved slightly. $34 \%$ of the respondents in East, $41 \%$ in the North and $25 \%$ in the South zone agree that their ability to save on educational expenses has stayed the same. $12 \%$ in the North and $18 \%$ in the South zone agree that their ability to save on educational expenses has shrunk greatly.7\% of the respondents in the North zone did not mention anything about ability to save on educational expenses. $31 \%$ of the respondents in the Rural area agree that their ability to save on educational expenses has improved slightly. 32\% of the married respondents agree that their ability to save on educational expenses has improved slightly.

Investment on fixed assets: $34 \%$ of the respondents in the East, $54 \%$ in the North and $31 \%$ in the South zone agree that their ability to invest on fixed assets has improved slightly. $34 \%$ of the respondents in the East, $32 \%$ in the North and $23 \%$ in the South zone agree that their ability to invest on fixed assets has stayed the same. $18 \%$ in the North and $20 \%$ in the South zone agree that their ability to invest on fixed assets has shrunk greatly. $12 \%$ of the respondents in the West and $8 \%$ in the North zone did not mention anything about ability to invest on fixed assets. 33\% of the respondents in the Rural area agree that their ability to invest on fixed assets has improved slightly. 33\% of the married respondents agree that their ability to invest on fixed assets has improved slightly.

Investments on non-fixed assets: $39 \%$ of the respondents in the West zone agree that investments on non-fixed assets have improved slightly. $38 \%$ of the respondents in the East zone agree that investments on non-fixed assets have stayed the same. $21 \%$ in the North and $22 \%$ in the South zone agree that investments on non-fixed assets have shrunk greatly. $16 \%$ of the respondents in the West and $7 \%$ in the North zone did not mention anything about investments on non-fixed assets. 31\% of the respondents in the Rural area agree that investments on non-fixed assets have improved slightly. $30 \%$ of the married respondents agree that investments on non-fixed assets have improved slightly. 
Purpose for loans taken: From the study, it is found that $39 \%$ of the respondents in North and $49 \%$ in the South zone took a loan for agriculture. $48 \%$ of the respondents in the West zone took a loan for income generating activities. $15 \%$ of the respondents in the East zone took a loan for buildings. $4 \%$ of the respondents in the East zone took a loan for other reason. 29\% of the respondents in the North did not mention anything about the purpose of the loan. $43 \%$ of the respondents in the Rural area took a loan for agriculture. $44 \%$ of the married respondents took a loan for agriculture.

\subsubsection{Findings of Objective 2}

Objective 2: To Build a Model of Empowerment for Women in agriculture Sector

- The financial factor is the most important Empowerment Quotient for women entrepreneurs in agriculture sector.

- The human factor is the second most important Empowerment Quotient for women entrepreneurs in agriculture sector

\section{Conclusion}

According to McKinsey Global Institute Report (Woetzel et al., 2015), the global economy can gain by $\$ 12$ trillion in the presence of true gender equality. Empowerment of women in social, human, financial, and intellectual aspects will ensure that the UN sustainable Development Goals will be reached by 2030. Unless our government works on the above schemes which includes programmes on gender equality, economic sustainability and financial literacy and financial inclusion of women, the 2030 global development goals cannot be reached. From the study, it is seen that reducing disparity across the world in economic terms can be achieved only by promoting gender equality and empowering women. How equality for women could drive $\$ 12$ trillion in global growth puts forth the fact that Indian women need to be empowered with respect to the five quotients namely social, financial, human, intellectual, leadership skill development, and mentoring factors. Among these quotients, it is the financial and human quotient which has to be given prominence. According 
to Amartya Sen, a critical step to economic empowerment is to ensure gender equality in our country. Access to education and basic health services hold the key. However, present policies by the government, emphasis on rural, agricultural and woman development schemes are surely signs of encouragement.

\section{Recommendation}

Women in India are accustomed to doing rigorous agricultural work as well as taking care of children and the home which is undervalued and underpaid. Their entire work schedule should be captured in a portal that can be tracked. Else, a large time (productivity) in household chores will remain untracked. Hence, an equivalence method has to be devised compared to men, working in the same sector. Though certain areas in India are woman-headed societies, most have a different story to tell. However, distribution of land based on gender bias cannot be a proper solution. Digital footprints have to be accompanied by easy microfinance from Banks and NBFCs to cultivate the culture and help in creating more successful women entrepreneurs in this field.

\section{References}

Anitha, H.S. \& Rao, K. R. (2013). SWOT analysis of rural women entrepreneurship in India-An overview. In Rural women entrepreneurship in India. ISBN - $978-81$ - $928540-0$ - 7

Arun. (2009). Microfinance: a rural household study in Davangere, Karnataka. In Microfinance and sustainable livelihood promotions and sustainable livelihood promotions in India, 251 - 258. ISBN - 978 - 81 $7446-937-3$

Woetzel, J., Madgavkar, A., Ellingrud, K., Labaye, E., Devillard, S., Kutcher, E., Manyika, J., Dobbs, R., \& Krishnan, M. (2015). How advancing women's equality can add $\$ 12$ trillion to global growth Retrieved from https://www.mckinsey.com/featured-insights/ employment-and-growth/how-advancing-womens-equality-can-add12-trillion-to-global-growth 